\title{
KNOWLEDGE AND ATTITUDES OF PAEDIATRIC DENTISTS IN TURKEY REGARDING CONE BEAM COMPUTED TOMOGRAPHY (CBCT)
}

\begin{abstract}
Objectives: The use of cone-beam computed tomography (CBCT) in dental practice has increased in recent years due to the lower radiation dose, fast scanning time, and superior imaging quality compared to conventional computed tomography (CT). Although CBCT is frequently preferred for the evaluation of the craniofacial region in areas such as orthodontics, orthognathic surgery, head trauma, and implant surgery, its use is still limited in paediatric dentistry. The aim of this study was to evaluate the knowledge and attitudes of paediatric dentists in Turkey regarding CBCT.
\end{abstract}

Materials and Methods: A self-administered anonymous questionnaire consisting of 17 questions was completed by 273 volunteer participants. Of these, 135 were postgraduate students in a paediatric dentistry program and 137 were $\mathrm{PhDs}$ or specialists. Relationships between categorical variables were evaluated using chisquare test.

Results: 237 (86.8\%) of the 273 participants stated that they were knowledgeable about CT/CBCT, but $81 \%$ of the respondents said the information they received during dental education was insufficient. The only significant relationship among the studied variables was between the participants' self-rated knowledge about the use of CT and/or CBCT for the dentomaxillofacial region and the institution in which they worked $(\mathrm{P}=.001)$.

Conclusions: Although our results indicate that paediatric dentists have high levels of knowledge and positive attitudes towards digital imaging techniques and CBCT, it would be beneficial to update the dental curricula and enable dental students to gain practical experience in addition to theoretical knowledge.

Keywords: Pediatric dentistry, CBCT, digital imaging methods, knowledge, attitude.

\author{
Ayşe Ișil Orhan ${ }^{1}$ \\ *Emre Cesur ${ }^{2}$ \\ Tuğba Bezgin ${ }^{3}$ \\ Kaan Orhan ${ }^{4}$
}

ORCID IDs of the authors:

A.I.O. 0000-0002-9559-0706

E.C. $\quad 0000-0003-0176-8970$

T.B. $\quad 0000-0002-3025-308 \mathrm{X}$

K.O. 0000-0001-6768-0176

\footnotetext{
${ }^{1}$ Department of Pediatric Dentistry, Faculty of Dentistry, Yıldırım Beyazıt University, Ankara, Turkey.

2 Department of Orthodontics, Faculty of Dentistry, İstanbul Medipol University, İstanbul, Turkey.

${ }^{3}$ Department of Pediatric Dentistry, Faculty of Dentistry, Ankara University, Ankara,Turkey.

${ }^{4}$ Department of Oral and Maxillofacial Radiology, Faculty of Dentistry, Ankara University, Ankara, Turkey.
} 


\section{INTRODUCTION}

The use of cone-beam computed tomography (CBCT) in dental practice has increased in recent years for various reasons, ranging from the lower radiation dose and fast scanning time to the fact that it provides detailed images with fewer artefacts compared to conventional tomography. Although CBCT is frequently preferred for the evaluation of the craniofacial region areas such as orthodontics, orthognathic surgery, head trauma, and implant surgery, its use in paediatric dentistry is still limited. ${ }^{1,2}$

Dhillon and Kalra ${ }^{1}$ stated that CBCT could be used in paediatric dentistry for applications such as evaluation of dental development, assessment of impacted/supernumerary teeth, evaluation of root morphology in endodontic procedures, detection of post-traumatic root fracture, and diagnosis of caries and lesions involving hard tissue. In contrast, Theodorakou et al. ${ }^{3}$ recommended using CBCT in the paediatric population only when absolutely necessary and after optimization.

CBCT involves a higher radiation dose than panoramic and intra-oral imaging but a lower dose compared to conventional tomography., ${ }^{4,7}$ When evaluating an individual's radiation risk, the effective doses recommended by ICRP (International Commission on Radiological Protection) should be kept in mind. Using anthropometric phantom models, Theodorakou et $a .^{3}$ determined that the lowest effective dose was achieved by selecting the smallest fields of view (FOV) and using small patient size settings. Vertical and horizontal collimation was recommended for CBCT units with only large FOV.

Despite the advantages mentioned above, ensuring the effective use of CBCT in dental practice is still crucial. Previous studies aiming to measure the attitudes and knowledge levels regarding the use of CBCT among students of dentistry and its various subfields revealed the need to improve knowledge and practices. ${ }^{8-10}$ Especially considering the effects of X-rays on the DNA of growing individuals, the paediatric population deserves the most caution concerning the use of CBCT. Therefore, this study aimed to evaluate knowledge and attitudes regarding the use of CBCT among paediatric dentists in Turkey.

\section{MATERIALS AND METHODS}

A questionnaire including questions about demographic information as well as general knowledge about and attitudes toward $\mathrm{CBCT}$ was prepared by the researchers (A.I.O., K.O., E.C.). Before starting the study, the questionnaire was evaluated for comprehensibility and consistency by 3 experts (2 paediatric dentists and 1 biostatistician). From the initial 20 questions, 3 items evaluated as biased or confusing by the expert panel were omitted, resulting in a final questionnaire comprising 17 questions (Figure 1). 
1. Age:

2. Gender: Female () Male ()

3. Title:

() Post-graduate student on a pedodontics program

() $\mathrm{PhD}$ or specialist

4. Institution:
() University
() Community oral and dental health center
() Private Practice
() Other:

5. How many years have you been working as a pediatric dentist (including the first year of the post-graduate pedodontics program)?

6. Do you use digital dental imaging methods?
() Yes
( ) No

7. Please indicate your reasons for using digital imaging methods (multiple choice is allowed):
() Reduced radiation dose
() Reduced time to obtain images
() Ease of the measurement and evaluation on images
() Reduced enviromental harm
() Other:

8. If you don't use digital imaging methods, please indicate the reasons (multiple choice is allowed):
( ) Expenaive
() Poor image quality
( ) Difficulty to perform
() Lack of knowledge
() Lack of access to the necessary equipments in my institution
() Other:

9. Do you have information about $\mathrm{CT}$ and/or CBCT use for dentomaxillofacial region?
( ) Yes
( ) No

10. If you have information about $\mathrm{CBCT}$, how did you obtain that information (multiple choice is allowed)?
( ) University education
() Seminar/ course/ congress
( ) Internet
() Written scientific documents
() Other:

11. Do you believe that you received sufficent information about $\mathrm{CBCT}$ during your dental education?
() Yes
( ) No

12. Do you have access to $C B C T$ at your ingtitution?
() Yes
( ) No

13. With the developing technology, do you think that the use of CBCT will become widespread in the field of pedodontics?
( ) Yes
( ) No
( ) No idea

14. Which method would you prefer for the visualization of the head and neck region in children if necessary?
( ) $\mathrm{CBCT}$
( ) $\mathrm{CT}$
( ) No idea

15. Please list the advantages of CBCT over CT from the most important (1) to the least important (4):
() Reduced radiation dose
() More affordable
() Achieving images in a shorter time
() Less space requiring
() Other:

16. Do you think the use of CBCT is necessary in the field of pedodontics?
( ) Yes
( ) No
() No idea

17. If you do, in what situations do you prefer to use CBCT in children?

() Evaluation of tooth development

() Diagnosis of caries and/or periapcal lesions

( ) Evaluation of impacted and/ or supernumerary teeth

() Evaluation of root resorbtions or root fractures

( ) Diagnosis and follow-up in traumas associated with dentoalveolar region

() Evaluation of defects and pathologies associated with maxilla and/or mandible

( ) Evaluation of deformities and syndromes involving the craniofacial region
( ) Other:

Figure 1. The questionnaire used in the survey. 
Ethical approval for the study was obtained from İstanbul Medipol University Ethics Committee (IRB number: 973).

The survey was conducted between July 2019 and December 2019. The self-administered, anonymous questionnaire was sent by one of the researchers (T.B.) via e-mail and/or website (www.surveymonkey.com) to 490 paediatric dentists who were members of the Turkish Association of Paediatric Dentistry. Of those invited, 290 (59\%) started the survey, but only the responses of the 273 participants $(56 \%$, mean age: $32 \pm 7.5$ years) who continued the questionnaire to the end were included in the analysis.

The evaluation of the participants' responses was carried out by all of the researchers. As participants were asked to answer the questions they wanted, the items they skipped were not taken into consideration in the evaluation. All questionnaires were recorded on the website (www.surveymonkey.com) and stored until evaluation. Data analyses were done using the IBM SPSS version 21 (SPSS Inc. Chicago, Illinois, USA) statistics package program. Relationships between categorical variables were evaluated using chi-square test. The significance level was accepted as $\mathrm{P}<.05$.

\section{RESULTS}

Analysis of the demographic data showed that the respondents' mean age was $32 \pm 7.5$ years (Question 1 [Q1]; Table 1), and most respondents (87.5\%) were women (Q2) (Table 2). Postgraduate students accounted for $49.6 \%$ of the participants $(\mathrm{n}=135)$, while the rest were $\mathrm{PhDs}$ or specialists (Q3). Most of the participants were employed in university hospitals $(76.5 \%)$, followed by private practice $(15.1 \%)$ and community oral and dental health centres (8.5\%) (Q4; Table 2). The participants' experience in the field of paediatric dentistry was $7.2 \pm 7.4$ years on average, ranging from 36 years to the first year of a postgraduate paediatric dentistry program (Q5; Table 1$)$

Table 1. Distribution of age (Q1) and years of experience as a paediatric dentist (Q5)

\begin{tabular}{lcccccc}
\hline & $\mathbf{n}$ & Mean & Median & Min. & Max. & \pm SD \\
\hline Age (Q1) & 273 & 32.0 & 29 & 21 & 60 & \pm 7.5 \\
$\begin{array}{l}\text { How many years have you been working as a } \\
\text { paediatric dentist (including the first year of the } \\
\text { post-graduate pedodontics program)? (Q5) }\end{array}$ & 273 & 7.2 & 4 & 0 & 36 & \pm 7.4 \\
\hline
\end{tabular}

Min: Minimum, Max: Maximum, SD: Standard deviation

Regarding the attitudes of the paediatric dentists towards the use of digital dental imaging methods, 91.5\% stated that they utilized digital methods (Q6; Table 3). The most common reasons cited for using digital imaging were faster results $(87.5 \%)$, ease of measurement and evaluation of images (82.3\%), lower radiation dose $(75.4 \%)$, less environmental harm (51.6\%), and other (2.4\%) (Q7; Table 2). Participants who marked "other" for Q7 explained their reasons as being able to visualize the images in
3 dimensions ( $\mathrm{n}=1)$, that it was used in the institution where they work $(n=2)$, and the high quality images $(n=3)$. When participants who did not use digital imaging methods were asked why not, all (100\%) cited the lack of access to the necessary equipment in their institutions. This option was followed by cost (95.7\%), finding it difficult to perform (52.2\%), lack of knowledge (47.8\%), and poor image quality (39.1\%) (Q8; Table 2).

Table 2. Demographic distribution of the participants and the distribution of their responses to Q7, Q8, and Q17.

\begin{tabular}{llcc}
\hline & & $\mathbf{n}$ & $\mathbf{\%}$ \\
\hline \multirow{3}{*}{ Gender (Q2) } & Male & 34 & 12.5 \\
& Female & 238 & 87.5 \\
& Total & 272 & 100.0 \\
\multirow{3}{*}{ Title (Q3) } & Post-graduate student on a pedodontics program & 135 & 49.6 \\
& PhD or specialist & 137 & 50.4 \\
& Total & 272 & 100.0 \\
Institution (Q4) & University & 208 & 76.5 \\
& Community oral and dental health centre & 23 & 8.5 \\
\hline
\end{tabular}


Orhan AI, et al.

\begin{tabular}{|c|c|c|}
\hline Other & 0 & 0 \\
\hline Total & 272 & 100.0 \\
\hline \multicolumn{3}{|c|}{ Please indicate your reasons for using digital imaging methods (multiple choices are allowed) (Q7) } \\
\hline Reduced radiation dose & 187 & 75.4 \\
\hline Shorter imaging time & 217 & 87.5 \\
\hline Ease of measurements and evaluation of images & 204 & 82.3 \\
\hline Reduced environmental harm & 128 & 51.6 \\
\hline Other & 6 & 2.4 \\
\hline \multicolumn{3}{|c|}{ If you do not use digital imaging methods, please indicate the reasons (multiple choices are allowed) (Q8) } \\
\hline Expensive & 22 & 95.7 \\
\hline Poor image quality & 9 & 39.1 \\
\hline Difficulty to perform & 12 & 52.2 \\
\hline Lack of knowledge & 11 & 47.8 \\
\hline Lack of access to the necessary equipment in my institution & 23 & 100.0 \\
\hline \multicolumn{3}{|l|}{ If you do, in what situations do you prefer to use CBCT in children? (Q17) } \\
\hline Evaluation of defects and pathologies associated with the maxilla and/or mandible & 210 & 93.8 \\
\hline Evaluation of impacted and/or supernumerary teeth & 196 & 87.5 \\
\hline Diagnosis and follow-up of traumas associated with the dentoalveolar region & 167 & 74.6 \\
\hline Evaluation of deformities and syndromes involving the craniofacial region & 167 & 74.6 \\
\hline Evaluation of root resorption or root fractures & 146 & 65.2 \\
\hline Evaluation of tooth development & 26 & 11.6 \\
\hline Diagnosis of caries and/or periapical lesions & 17 & 7.6 \\
\hline Other & 4 & 1.8 \\
\hline
\end{tabular}

When the paediatric dentists were asked to rate their knowledge of CBCT, 237 (86.8\%) of the 273 participants stated that they were knowledgeable about CBCT/CT (Q9; Table 3). Reported sources of this information included university education (68.4\%), written scientific documents (14.8\%), seminars/courses/congresses (12.1\%), the internet (2.7\%), and other (2\%; observation, during $\mathrm{PhD}$ education, from experienced users) (Q10; Table 3).
Although most participants stated that they learned about CBCT during their dental education, $81 \%$ replied negatively when asked if sufficient information was provided during dental education (Q11; Table 3). While 64.9\% of the participants $(\mathrm{n}=176)$ reported that they had access to CBCT in the institution they worked in, the remaining 95 (35.1\%) stated that they did not (Q12; Table 3).

Table 3: Distribution of the participants' responses to Q6, Q9, Q10, Q11, Q12, Q13, Q14, and Q16.

Do you use digital dental imaging methods? (Q6)

Do you have information about $\mathrm{CT}$ and/or CBCT use for dentomaxillofacial region? (Q9)

If you have information about CBCT, how did you obtain that information (multiple choices are allowed) (Q10)

Do you believe that you received sufficient information about CBCT during your dental education? (Q11)

Do you have access to CBCT at your institution? (Q12)

\begin{tabular}{lcc} 
& $\mathbf{n}$ & \% \\
Yes & 248 & 91.5 \\
No & 23 & 8.5 \\
Total & 271 & 100.0 \\
Yes & 237 & 86.8 \\
No & 36 & 13.2 \\
Total & 273 & 100.0 \\
University Education & 175 & 68.4 \\
Seminar/ course/ congress & 31 & 12.1 \\
Internet & 7 & 2.7 \\
Written scientific documents & 38 & 14.8 \\
Other & 5 & 2.0 \\
Total & 256 & 100.0 \\
Yes & 51 & 19.0 \\
No & 218 & 81.0 \\
Total & 269 & 100.0 \\
Yes & 176 & 64.9 \\
No & 95 & 35.1 \\
Total & 271 & 100.0 \\
\hline
\end{tabular}




\begin{tabular}{llcc}
\hline With the developing technology, do you think that the use of & Yes & 193 & 71.2 \\
CBCT will become widespread in the field of pedodontics? & No & 38 & 14.0 \\
(Q13) & Not sure & Total & 40 \\
& CBCT & 271 & 100.0 \\
& CT & 225 & 82.4 \\
Which method would you prefer for the visualization of the & Not sure & 17 & 6.2 \\
head and neck region in children if necessary? (Q14) & Total & 31 & 11.4 \\
& Yes & 273 & 100.0 \\
Do you think the use of CBCT is necessary in the field of & No & 224 & 82.1 \\
pedodontics? (Q16) & Not sure & 20 & 7.3 \\
& Total & 29 & 10.6 \\
\hline
\end{tabular}

When the participants currently practicing in the field of paediatric dentistry were asked whether CBCT use will be widespread in their fields, 193 participants answered "yes" (71.2\%), 38 participants said "no" (14\%), and the other 40 participants (14.8\%) answered "not sure" (Q13, Table 3). When asked which method they would prefer for imaging of the head and neck in children if necessary, 225 participants $(82.4 \%)$ selected CBCT, 17 (6.2\%) chose CT, and 31 participants (11.4\%) answered "not sure" (Q14; Table 3).
When participants were asked to list the advantages of CBCT over CT from the most important (1) to the least important (4), 218 participants $(85.5 \%)$ ranked the reduced radiation dose first, while the second most selected option was shorter imaging time, with $67.2 \%$. The third and fourth most often marked options were lower cost and less space required, respectively (Q15, Table 4).

Table 4. Distribution of the participants' responses to Q15.

\begin{tabular}{|c|c|c|c|c|c|c|c|c|c|c|}
\hline & & \multicolumn{2}{|c|}{1} & \multicolumn{2}{|c|}{2} & \multicolumn{2}{|c|}{3} & \multicolumn{2}{|c|}{4} & \multirow[t]{2}{*}{ Total } \\
\hline & & $\mathbf{n}$ & $\%$ & $\mathbf{n}$ & $\%$ & $\mathbf{n}$ & $\%$ & $\mathbf{n}$ & $\%$ & \\
\hline \multirow{6}{*}{$\begin{array}{l}\text { Please list } \begin{array}{r}\text { the } \\
\text { advantages }\end{array} \\
\text { CBCT over CT } \\
\text { from the most } \\
\text { important (1) to the } \\
\text { least important (4) } \\
\text { (Q15) }\end{array}$} & $\begin{array}{l}\text { Reduced radiation } \\
\text { dose }\end{array}$ & 218 & 85.49 & 12 & 4.71 & 3 & 1.18 & 0 & 0.00 & 228 \\
\hline & More affordable & 6 & 2.47 & 48 & 19.75 & 129 & 53.09 & 50 & 20.58 & 233 \\
\hline & Shorter imaging time & 8 & 3.16 & 170 & 67.19 & 50 & 19.76 & 8 & 3.16 & 236 \\
\hline & Requires less space & 5 & 2.08 & 5 & 2.08 & 55 & 22.92 & 162 & 67.50 & 227 \\
\hline & Other & 2 & 1.23 & 4 & 2.47 & 1 & 0.62 & 14 & 8.64 & 21 \\
\hline & Not sure & 11 & 6.63 & 1 & 0.60 & 2 & 1.20 & 2 & 1.20 & 16 \\
\hline
\end{tabular}

Most participants $(\mathrm{n}=224,82.1 \%)$ considered CBCT use necessary in paediatric dentistry, but 20 $(7.3 \%)$ stated that it was not necessary and 29 $(10.6 \%)$ reported having no opinion on the subject (Q16, Table 3). When asked in which situations they preferred to use CBCT in children, the most selected option was evaluation of defects and pathologies associated with the maxilla and/or mandible $(n=210,93.8 \%)$, while the least selected option was diagnosis of caries and/or periapical lesions $(n=17,7.6 \%)$. Individuals who selected the "other" option stated that they used it to determine the prognosis of apexification and apexogenesis treatments $(\mathrm{Q} 17$, Table 2).

When inter-variable dependence was assessed using chi-square test between all questions, the only significant relationship detected was between responses to "Are you knowledgeable about the use of CT and/or CBCT for the dentomaxillofacial region?" and the participants' institution. Employees of community oral and dental health centres responded "yes" to this question significantly less frequently $(60.9 \%)(\mathrm{P}=.001)$ (Table 5). 
Table 5. Cross-evaluation of $\mathrm{Q} 4$ and $\mathrm{Q} 9$. (Chi-square test; $\left.\mathrm{P}=.05^{*}, \mathrm{P}=.01 * *, \mathrm{P}=.001 * * *\right)$

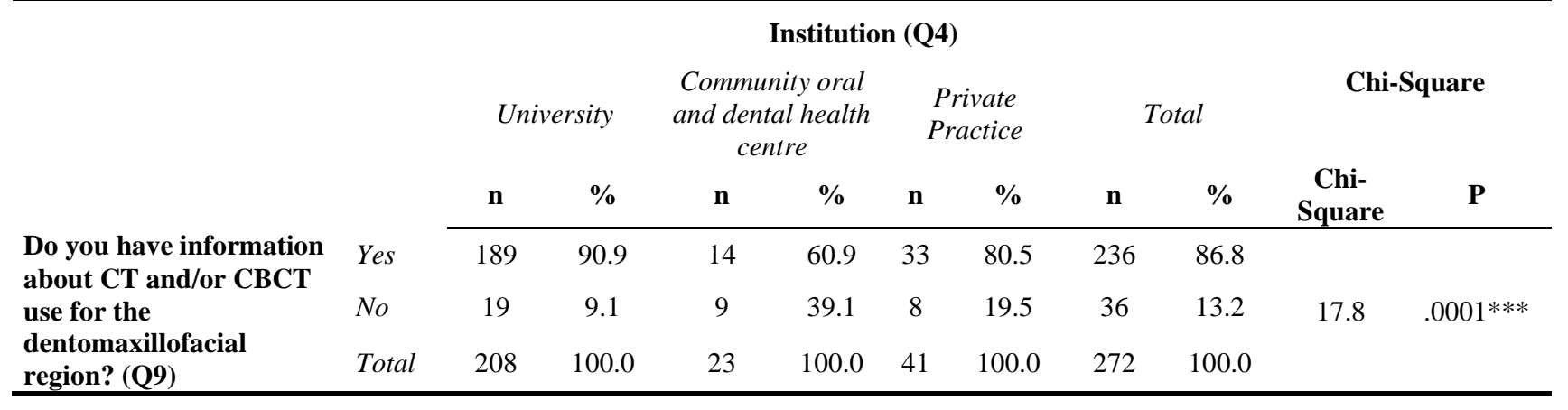

\section{DISCUSSION}

With advancing technology, CBCT has been widely adopted in nearly all areas of dentistry and is the most accepted 3D imaging method in current practice. As its use increases, the radiation-related effects of CBCT raise concerns about its use in the paediatric population. $\mathrm{Aps}^{2}$ proposed three basic principles to protect children from unnecessary radiation. Radiographs should not be taken from paediatric patients unless there is an absolute indication, (justification principle), the radiation dose should be minimized (limitation principle), and it should be attempted to obtain the most appropriate diagnostic images (optimization principle). Oenning et al. ${ }^{6}$ launched the DIMITRA (dentomaxillofacial paediatric imaging: an investigation toward low-dose radiation-induced risks) project and advocated the necessity to move from the principles of ALARA (as low as reasonably achievable) and ALADA (as low as diagnostically acceptable) toward ALADAIP (as low as diagnostically acceptable being indicationoriented and patient-specific) principles. Knowing about digital imaging methods and CT/CBCT is especially important for paediatric dentists and orthodontists, as they work more with the paediatric population. To our knowledge, there is only one study evaluating attitudes towards CBCT among paediatric dentists. ${ }^{11}$ Therefore, in this study we aimed to investigate this issue in detail.

Most of the paediatric dentists included in our study stated that they used digital imaging methods. The reasons most commonly given for their use were the faster imaging and ease of measurement and image analysis, consistent with a previous study. ${ }^{11}$ However, among individuals who did not use digital imaging, the main factor was identified as lack of access to the necessary equipment in their institution. Lavanya et al. ${ }^{9}$ reported that limited $\mathrm{CBCT}$ use was associated with limited access to CBCT in the workplace, while Kamburoğlu et al. ${ }^{8}$ reported in their survey study of Turkish dentistry students that their lack of knowledge about CBCT may be related to technical deficiencies in their institution and lack of practical experience. Our findings were consistent with these previous studies. The fact that academicians in our study reported greater knowledge of CBCT may be due to having more practical experience.

The majority of the participants (86.8\%) answered positively when asked if they were knowledgeable about CT/CBCT. This result is higher than that reported by Eren Giray et al. ${ }^{11}$, who stated that $30 \%$ of the paediatric dentists in their study did not have knowledge regarding CBCT. This discrepancy may be due to the inclusion of paediatric dentists from different countries in Eren Giray's study. The authors noted that more Turkish paediatric dentists reported having knowledge of CBCT than paediatric dentists from other countries. ${ }^{11}$ Most of the participants in the present study stated that they learned this information during their university education. However, a significant number of participants still reported that they did not obtain sufficient information on this subject during dental training. The results of previous studies evaluating the competence of dentists, dentistry students, and orthodontists in education also demonstrated the inadequacy of dentistry education in this regard. ${ }^{8-}$ 10,12 These results show that dental students should be provided more theoretical as well as practical information regarding $\mathrm{CBCT}$. 
In our evaluation of the relationships between variables assessed in the questionnaire, we observed that knowledge regarding the use of CT and/or CBCT differed significantly based on the participants' institutions. Self-reported knowledge was lowest among paediatric dentists practicing in community oral and dental health centres and highest among paediatric dentists working in universities. Geçgelen Cesur et al. ${ }^{10}$ reported that $\mathrm{CBCT}$ use is more common at universities because of their status as 'leading-edge' technological institutions. Therefore, to increase knowledge of CBCT among paediatric dentists, undergraduate dentistry curricula should be modified to maintain, expand, and update education on this topic and provide access to this technology. The responses to our survey showed that most paediatric dentists use CBCT when evaluating the head and neck region and they think CBCT is necessary in the dentistry subfields, but our results also indicate that attained knowledge levels are not adequate.

One of the biggest advantages of CBCT in paediatric patients is that it reduces children's anxiety due to the decreased scan time. Furthermore, compared to conventional CT, CBCT images are higher quality with less distortion. However, the most important advantage of CBCT is the lower radiation dose. ${ }^{2}$ Although the dose is still substantially higher than from intra-oral radiographs, a $51 \%$ to $96 \%$ reduction has been reported compared to conventional $\mathrm{CT}^{4}{ }^{4}$ The paediatric dentists who participated in the current study prioritized the lower radiation dose and faster results as the main reasons they preferred CBCT. That said, the safe use of CBCT in children depends on it being applied for the correct indications and using the correct technique.

There are many reports and studies on the use of CBCTs in dentistry. In their review of studies documenting the use of CBCT in different areas of dentistry, de Vos et al. ${ }^{13}$ reported that the use of CBCT was more common in the fields of maxillofacial surgery (41\%), dentoalveolar problems (29\%), orthodontics (16\%), and dental implantology $(11 \%)$. Its ability to provide detailed information about the anatomical structures of the region explains the popularity of $\mathrm{CBCT}$ in maxillofacial surgery in particular. ${ }^{14-16}$ In addition, it is commonly used in orthodontics for guiding impacted teeth into alignment, evaluating syndromes/deformities involving the maxillofacial area, examining the airway, and planning orthognathic surgery and measurements of craniofacial morphology. ${ }^{17,18}$ Although the use of CBCT for the dentoalveolar region is limited, some publications have described its use in caries evaluation. ${ }^{19,20}$ According to Tyndall and Rathore $^{19}$, CBCT can also be beneficial in the examination of periodontal bone and endodontic applications. In a review evaluating the use of CBCT in the field of endodontics, it was stated that CBCT would be useful in preoperative procedures such as the evaluation of periapical pathologies, root fractures, and resorption and/or postoperative evaluations. In their systematic review, Horner et al. ${ }^{7}$ stated that the use of CBCT for caries detection is not indicated in the paediatric population, but it may be indicated in cases such as acute infections and root resorption and fractures, where conventional radiographs are inadequate. According to the researchers, CBCT is indicated for the evaluation of developmental deformities and large bone defects. İşman et al. ${ }^{21}$ reported that the most common indications of CBCT in the paediatric population and adolescents were dentomaxillofacial anomalies and localization of buried teeth.

When the paediatric dentists participating in the present study were asked for which purposes they used CBCT, the most common responses were evaluation of defects and pathologies associated with the maxilla and/or mandible, evaluation of impacted and/or supernumerary teeth, and the diagnosis and follow-up of trauma patients, while the least selected options were diagnosis of caries and/or periapical lesions and evaluation of tooth development. These findings are consistent with the results of previous studies, suggesting that paediatric dentists are knowledgeable about the indications of CBCT. Paediatric dentists are the front-line clinicians who diagnose and treat patients with trauma and dental/alveolar pathologies. Therefore, they should have current knowledge of the best diagnostic tools to help their patients. Although the results of this study showed 
that paediatric dentists in Turkey generally know the correct indications for $\mathrm{CBCT}$, this knowledge should be increased.

\section{CONCLUSIONS}

CBCT is one of the most important methods in current dental radiology due to advantages such as lower radiation dose and improved image quality. Our results indicate that paediatric dentists in Turkey have high levels of knowledge and positive attitudes regarding digital imaging techniques and CBCT. However, their knowledge could be further increased by updating the dental curriculum and providing practical experience in addition to theoretical knowledge. In addition, continuing education programs should be developed to inform and increase accessibility for paediatric dentists not working at universities.

\section{ACKNOWLEDGEMENTS}

None to declare

\section{CONFLICT OF INTEREST}

All authors declare no conflict of interest.

\section{FUNDING}

None to declare

\section{$\ddot{O} Z$}

Amaç: Konik ışınlı bilgisayarl tomografilerin (KIBT) diş hekimliğinde kullanımı son yıllarda oldukça yaylmaktadlr. KIBT; ortodontide, ortognatik cerrahide, kafa travmalarinda ve implant cerrahisinde, kraniyofasiyal bölgenin değerlendirilmesinde oldukça sik kullanılsa da, pedodontide kullanımı halen sinırlıdır. $\mathrm{Bu}$ çalışmanın amacı, Türkiye'de pedodontistler arasında KIBT kullanımına yönelik bilgi ve tutumun değerlendirilmesidir. Gereç ve Yöntemler: Bu çalışma 273 gönüllü katılımcı ile gerçekleştirilmiş olup, katıllmcilardan kendi kendine yönetilen ve 17 sorudan oluşan bir anketi isimsiz olarak doldurmaları istenmiştir. Katıllmcıların 135 'ini doktora/uzmanlık öğrencileri oluştururken, 137'si pedodonti doktoru ve/veya uzmanıdır. Bu araştırmada, kategorik değişskenler arası ilişsilerin incelenmesinde chi-kare testi kullanılmuştır. Bulgular: $237(\% 86,8)$ katılımcı BT/KIBT hakkında bilgi sahibi olduğunu belirtmişstir. Katılımcıların \%81'i diş hekimliği eğitimi sirasında aldıkları bilginin yetersiz olduğunu bildirmiştir. Değisskenler arası bağımlılık değerlendirildiğinde, anlaml tek fark, kattlimcıların BT/KIBT kullanımı konusunda bilgi sahibi olup olmadıklarına dair soru ile çalıștikları kurum arasında bulunmuştur $(P=, 001)$. Sonuçlar: Çalı̧̧mamızın sonuçları, pedodontistlerin dijital görüntüleme yöntemleri ve KIBT kullanımına dair yüksek bilgiye sahip olduklarını ve olumlu tutum gösterdiklerini saptasa da, diş hekimliği müfredatının güncellenmesi ve öğrencilerin teorik bilginin yan sıra pratik tecrübe edinmelerinin sağlanmast, KIBT kullanımınin yayginlaşması ve yerinde kullanımının sağlanması açısından faydalı olacaktır. Anahtar kelimeler: Pedodonti, KIBT, dijital görüntüleme metodlaro, bilgi, tutum.

\section{REFERENCES}

1. Dhillon JK, Kalra G. Cone-beam computed tomography: An innovative tool in paediatric dentistry. J Pediatr Dent 2013;1:27-31.

2. Aps JK. Cone-beam computed tomography in paediatric dentistry: Overview of recent literature. Eur Arch Paediatr Dent 2013;14:131-140.

3. Theodoraou C, Walker A, Horner K, Pauwels R, Bogaerts R, Jacobs R, The Sedentxct Project Consortium. Estimation of paediatric organ and effective doses from dental cone beam CT using anthropomorphic phantoms. Br J Radiol 2012;85: 153160.

4. Roberts JA, Drage NA, Davies J, Thomas DW. Effective dose from cone beam CT examinations in dentistry. Br J Radiol 2009;82:35-40.

5. Shin HS, Nam KC, Park H, Choi HU, Kim HY, Park CS. Effective doses from panoramic radiography and CBCT (cone beam CT) using dose area product (DAP) in dentistry. Dentomaxillofac Radiol 2014;43:20130439.

6. Oenning AC, Jacobs R, Pauwels R, Stratis A, Hedesiu M, Salmon B, DIMITRA Research Group. Cone-beam $\mathrm{CT}$ in paediatric dentistry: DIMITRA project position statement. Pediatr Radiol 2018;48:308316.

7. Horner K, Barry S, Dave M, Dixon C, Littlewood A, Pang CL, Sengupta A, Srinivasan V. Diagnostic efficacy of cone-beam computed tomography in paediatric dentistry: a systematic review. Eur Arch Paediatr Dent 2019; doi: 10.1007/s40368-019-00504-x

8. Kamburoglu K, Kursun S, ZZ Akarslan ZZ. Dental students' knowledge and attitudes towards cone beam computed tomography in Turkey. Dentomaxillofac Radiol 2011;40:439-443 
9. Lavanya R, Gandhi Babu DB, Waghray S, Chaitanya NCSK, Mamatha B, Nithika M. A questionnaire cross-sectional study on application of CBCT in dental postgraduate students. Pol J Radiol 2016;81:181-189.

10. Geçgelen Cesur M, Yılmaz A, Özer T. Knowledge and attitudes towards digital radiography and CBCT among orthodontists. Biomed Res 2016;27:959-964.

11. Eren Giray F, Peker S, Ercalik Yalcinkaya S, Kargul B, Aps J. Attitudes and knowledge of paediatric dentists' on digital radiography and cone beam computed tomography. J Pak Med Assoc 2019;69:205-210.

12. Shetty SR, Castelino RL, Babu SG, Prasanna, Laxmana AR, Roopashri K. Knowledge and Attitude of Dentists towards Cone Beam Computed Tomography in Mangalore-A Questionnaire Survey. Austin J Radiol 2015;2:1016.

13. De Vos W, Casselman J, Swennen GR. Cone-beam computerized tomography (CBCT) imaging of the oral and maxillofacial region: A systematic review of the literature. Int J Oral Maxillofac Surg 2009;38:609-625.

14. Pohlenz P, Blessmann M, Blake F, Heinrich S, Schmelzle R, Heiland M. Clinical indications and perspectives for intraoperative cone-beam computed tomography in oral and maxillofacial surgery. Oral Surg Oral Med Oral Pathol Oral Radiol Endod 2007;103:412417.

15. Swennen GRJ, Mollemans W, Abeloos J, De Clercq C, Lamoral P, Lippens F, Mommaerts MY, Neyt N,
Casselman J, Schutyser F. A conebeam CT triple scan procedure to obtain a three-dimensional augmented virtual skull model appropriate for orthognathic surgery planning. J Craniofac Surg 2009;20:297-307.

16. Quereshy FA, Savell TA, Palomo JM. Applications of cone beam computed tomography in the practice of oral and maxillofacial surgery. J Oral Maxillofac Surg 2008;66:791-796

17. Kapila S, Conley RS, Harrell WE Jr. The current status of cone beam computed tomography imaging in orthodontics. Dentomaxillofac Radiol 2011;40:24-34.

18. Coşkun I, Kaya B. Cone Beam Computed Tomography in Orthodontics. Turk J Orthod 2018;31:55-61.

19. Tyndall DA, Rathore S. Cone-beam CT diagnostic applications: Caries, periodontal bone assessment, and endodontic applications. Dent Clin North Am 2008;52:825-841.

20.Zhang ZL, Qu XM, Li G, Zhang ZY, Ma XC. The detection accuracies for proximal caries by cone-beam computerized tomography, film, and phosphor plates. Oral Surg Oral Med Oral Pathol Oral Radiol Endod 2011;111:103-118.

21. İşman Ö, Yılmaz HH, Aktan AM, Yılmaz B. Indications for cone beam computed tomography in children and young patients in a Turkish subpopulation. Int J Paediatr Dent 2017;27:183-190. 